\title{
Assessing Secondary Students' Scientific Literacy: A Comparative Study of Suburban Schools in England and Malaysia
}

\author{
Mohd Syafiq Aiman Mat Noor* \\ Department of Education, School of Education, College of Business, Arts and Social Sciences, Brunel University London, United Kingdom \\ *Corresponding author: 1329645@alumni.brunel.ac.uk
}

\section{ABSTRACT}

This study sought to assess the level of secondary students' scientific literacy in suburban schools in Malaysia and England, a research area which to date has not been fully explored in the literature. The study analyzed the data using the OECD's three domain-specific competencies of scientific literacy, namely: (i) explain phenomena scientifically, (ii) evaluate and design scientific enquiry, and (iii) interpret data and evidence scientifically. To assess the level of secondary students' scientific literacy in these contexts, the study applied the scientific literacy assessment instrument called the "Nature of Scientific Literacy Test" (NOSLiT), first developed by Wenning (2006). The results indicated that the level of scientific literacy of English students was higher than that of Malaysian students across all three domain-specific competencies. Despite the fact that NOSLiT is a systematic and reliable instrument for assessing the level of students' scientific literacy, the study found that OECD's three domain-specific competencies of scientific literacy provided better insights into the level of secondary students' scientific literacy in Malaysian and English suburban schools. It is suggested that future studies should use a qualitative approach to both data collection and analysis to understand the level of students' scientific literacy in more detail.

KEY WORDS: Comparative study; scientific literacy; suburban school

\section{INTRODUCTION}

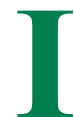
n recent years, "scientific literacy" has become increasingly prominent in international discussions about the aims and purposes of science education (McGregor and Kearton, 2010). For example, Gyllenpalm et al. (2010) emphasised the call for scientific literacy as a general goal of science education, highlighting that students need to develop an understanding beyond scientific concepts and skills. Although there are different interpretations of scientific literacy's meaning (DeBoer, 2000; Fensham, 2004; Hodson, 2002; Kolstø, 2001; Tippins et al., 2000), there is no clearly agreed and well-articulated definition (Hodson, 2008; Millar, 2008; Osborne, 2007). Norris and Phillips (2003) contended that the term scientific literacy incorporates various components, including: (i) knowledge of the substantive content of science and the ability to distinguish it from non-science, (ii) understanding science and its applications, (iii) knowledge of what counts as science, (iv) independence in learning about science, (v) ability to think scientifically, (vi) ability to use scientific knowledge in problem solving, (vii) knowledge needed for intelligent participation in science-based issues, (viii) understanding the nature of science, including its relationship with culture, (ix) appreciation of and comfort with science, including its wonder and curiosity, (x) knowledge of the risks and benefits of science, and (xi) ability to think critically about science and to deal with scientific expertise.
Many commentators on science education(Banilower etal., 2010; LoPresto, 2004; Sadeh and Zion, 2009; Wheeler, 2007; Zion et al., 2004) endorse the definition of scientific literacy provided by the United States' prestigious science organisation, the American Association for the Advancement of Science (AAAS). The Benchmarks for Science Literacy identified as part of Project 2061 articulate that:

When people know how scientists go about their work and reach scientific conclusions, and what the limitations of such conclusions are, they are more likely to react thoughtfully to scientific claims and less likely to reject them out of hand or accept them uncritically (AAAS, 1993, p. 3).

This definition is also reflected in the relatively current focus on "How Science Works" in the National Curriculum in England and signifies that the essential part of scientific literacy is an understanding of the nature of science itself - that is to say, how scientists arrive at scientific knowledge, as opposed to scientific knowledge per se (Toplis, 2010). The additional dimension of scientific literacy as the study of science relates to the fact that:

Once people gain a good sense of how science operates - along with a basic inventory of key science concepts as a basis for learning more later - they can follow the science adventure story as it plays out during their lifetimes. (AAAS, 1993, p. 3)

In short, people who become scientifically literate must be able to understand both the way science works, and the body 
of knowledge science has produced. This view resonates with Hodson's (2008) notion of universal critical scientific literacy. Hodson argued that what is included and left out is shaped by an ultimate goal: preparing students to take sociopolitical action in science-related matters, based on their capacity to interpret scientific information critically. He added that schools should be more politicized and curricular initiatives issue-based, to equip students with the capacity and commitment to take informed and effective action on matters of social, economic, environmental, moral, or ethical concern. Therefore, the study of science as an intellectual and social endeavor - the application of human intelligence to figuring out how the world works - should have a prominent place in any curriculum that has scientific literacy as one of its aims (AAAS, 1993).

Historically, four meanings have been associated with the term literacy or being able to describe someone as literate (Kintgen, 1988). Wellington and Osborne (2001) highlighted that science education should place a greater emphasis on scientific literacy based on these four levels. The lowest level is the ability to write and read your own name; the next stage is simply the recitation stage where an individual is able to recite, or read, information but has little understanding of the meaning of the words or their implications; the next level of literacy is the ability to comprehend unfamiliar material; and the highest form of literacy is the evaluative or analytical stage, in which readers are expected to analyse and critique what they read and to draw inferences (Bloom, 1956). Furthermore, Driver et al. (1996) highlighted that science curricula in practice provide training in science for a minority of students, and give access to basic scientific literacy for the majority, in which science is part of general education and one aspect of their preparation for life. He added that the aim of scientific literacy is to improve the numbers of scientifically literate adults in society and hence to improve public understanding of science. Therefore, the goal of broad scientific literacy applies as much to the aspiring specialist as to the student who will choose a non-science career path.

\section{Scientific Literacy in England's and Malaysia's School Science Curriculum}

Science education in the United Kingdom is compulsory from ages of four to 16 . Post-16 students now also have to study a minimum of three subjects and are encouraged to study at least four before selecting three for their final year. However, none of these needs to be a science subject (Osborne, 2000). The curriculum exists from age four to 16 and is specified in a government document entitled the "Science National Curriculum." The current national curriculum emphasises that science is a compulsory subject at all four key stages in England (DfE, 2014). Correspondingly, in the Malaysian national curriculum, science is a core subject in the school curriculum, and comprises science for primary and for secondary education, including, physics, biology, chemistry, and additional science (Syed Zin, 2000). The Malaysian science curriculum was developed centrally. At the primary and lower secondary levels, science is compulsory for all, while at the upper secondary level, students either take core science or choose science electives.

In the context of science curriculum aims, the national curriculum for science in England aims to ensure that all students: i) develop scientific knowledge and conceptual understanding through the specific disciplines of biology, chemistry and physics, ii) develop understanding of the nature, processes and methods involved in science through different types of scientific enquiries that help them to answer scientific questions about the world around them, and iii) are equipped with the scientific knowledge required to understand the uses and implications of science, today and for the future (DfE, 2014). Malaysia's science curriculum equally aims to provide students with: (i) the knowledge and skills in science and technology that enable them to solve problems and make decisions in everyday life based on scientific attitudes and noble values, (ii) a basic foundation in science to enable them to pursue formal and informal further education in science and technology, and (iii) the ability to develop a concerned, dynamic and progressive society with a scientific and technological culture that values nature and works toward the preservation and conservation of the environment (MOE, 2003).

Hurd (1958) attributed the first use of the term scientific literacy to the science curriculum, in the context of proposing goals for science education in the post-Sputnik era. He offered a brief review of the historical use and meanings of the term scientific literacy in science curriculum writings, drawing on sources from researchers in several countries (Bybee, 1997; DeBoer, 2000; Laugksch, 2000). DeBoer's (2000) extensive review of the history of science education further showed that there are at least nine separate and distinct goals of science education, all of which are related to the larger goal of scientific literacy. Osborne (2007) suggested that the primary goal of any science education should be to develop scientific literacy. He explored what that might consist of and why such an education is necessary in contemporary society. In the case of the curriculum in England, the major development within the UK is a course aptly titled "Twenty First Century Science," whose rationale and content was fully articulated in 2005 by Robin Millar, a Professor of Science Education at that time. The Qualifications and Curriculum Authority, the official regulator of the school curriculum and examinations in England, initiated the Twenty First Century Science pilot project (Millar, 2006).

While scientific literacy for all citizens is widely seen as an important goal for science education, the science curriculum also has to satisfy other demands (Millar, 2006). The tension between the two purposes of school science - scientific literacy for all and pre-professional training in science for some - is highlighted in the Beyond 2000 report (Millar and Osborne, 1998). This report emphasised that the primary and explicit aim of the science curricula should be to provide a course which can enhance scientific literacy, as this is necessary for all young people growing up in our society, whatever their career aspirations or aptitudes. The recommendations of the Beyond 2000 report were one of the key drivers in the 
development of the suite of Twenty First Century Science General Certificate of Secondary Education (GCSE) courses. The Twenty First Century Science curriculum model ensures that all students take a core science course, designed explicitly to develop their scientific literacy; alongside this they may choose to take an additional science course, which is offered with either a pure or applied emphasis (Millar, 2006). The two components of science explanations and ideas about science are the pillars of the Twenty First Century Science Core course.

The GCSE Science course aims to develop scientific literacy and views science from the perspective of a member of the public (Millar, 2006). It is taught in the context of topics of relevance and interest to young people, through a set of nine thematic modules (Table 1), on topics chosen to be of interest to students of the target age. It is meant for all students, as future scientists will also benefit from learning about how science works. Ratcliffe and Millar (2009) reported from the pilot trials of the Twenty First Century Science courses that: (i) students made progress in understanding over the duration of the course, in most contexts, (ii) students did not perform particularly strongly in questions that required them to develop explanations in familiar and novel contexts, and (iii) students, when responding to questions about ideas in science, were significantly better than the comparison group on questions about data and its limitations. The overall performance of the Twenty First Century Science students in demonstrating an understanding of basic scientific ideas/processes and applying scientific ideas to develop explanations was not significantly different from the comparison group. These findings were reinforced in Toplis's et al. (2010) study, which found that teachers cannot be guaranteed a full and engaging introduction to how science works in their practice schools, as many teachers are still teaching students to pass exams.

In the context of the science curriculum in Malaysia, scientific literacy was provisionally translated into the school science curriculum titled: the Integrated Curriculum for Secondary Schools; Science Syllabus (MOE, 2003). The core science subjects for the primary and lower secondary levels are designed to provide students with basic scientific knowledge, prepare students to be scientifically literate, and enable students to continue their science education at the upper secondary level.

\begin{tabular}{l}
\hline Table 1: Core science modules \\
\hline Modules \\
\hline You and your genes \\
Air quality \\
Earth in the Universe \\
Keeping healthy \\
Material choices \\
Radiation and life \\
Life on Earth \\
Food matters \\
Radioactive materials
\end{tabular}

Coupled with core science at the upper secondary level, it is designed to produce students who are scientifically literate, innovative, and able to apply scientific knowledge to decision-making and problem solving in everyday life. Based on the philosophy of science education, the science curriculum in Malaysia aims to nurture a culture centred on science and technology among students, by focusing on the development of individuals who possess the competitive, dynamic, resilient, and driven characteristics to master scientific knowledge and technological capabilities (MOE, 2003). This curriculum aim is translated in the science syllabus as it has been designed to provide opportunities for students to acquire scientific knowledge and skills. It also seeks to inculcate noble values and to develop a future generation which is capable of contributing to the harmony and prosperity of the nation and its people.

In the science curriculum, the infusion of scientific literacy into pedagogical approaches is recommended. Central to the teaching and learning approach in the science curriculum at all levels is the mastery of scientific skills, which comprise process skills, manipulative skills, and thinking skills (Syed Zin, 2000). Scientific and thinking skills are infused through science lessons at various stages. These stages range from explicitly introducing scientific and thinking skills, applying these skills with guidance from teachers, and finally applying these skills to solve specific problems independently. In essence, the integrated curriculum aims for the inculcation of scientific attitudes and noble values, spontaneously or through planned activities (MOE, 2003). The infusion of desirable values and attitudes is also emphasised in teaching approaches. Such values include showing interest in and curiosity towards one's surroundings, honesty and accuracy in recording and validating data, flexibility and open-mindedness, perseverance, being systematic and confident, cooperation, responsibility for one's own and others' safety, and for the environment, appreciation of the contributions of science and technology, thankfulness to God, appreciation and practice of a healthy and clean lifestyle, and the realisation that science is one of the ways to understand the universe (Syed Zin, 2000).

Despite the incorporation of scientific literacy into the curriculum aims for school science in Malaysia, most science teachers are likely to instruct students to carry out practical work following procedures laid out in textbooks, which can lead them to the desired outcome without much opportunity for discussion or without encouraging them to discover or inquire for themselves (Syed Zin, 2003). As a result, the science curriculum in Malaysia is unable to provide wide opportunities for students to develop their scientific literacy, as they merely conduct experiments and carry out practical activities, without any critical engagement with the material (Sikas, 2017). Findings from two international science assessments, namely the Trends in International Mathematics and Science Study (TIMSS) (Martin et al., 2012) and Program for International Student Assessment (PISA) (OECD, 2018) showed that Malaysian students did not perform well with regards to 
cognitive skills such as knowledge recall, ability in reasoning and the application of knowledge in problem solving. Scientific literacy, as measured in these assessments, is not only gauged through the level of understanding of science alone, but also through students' understanding of the various aspects of the scientific process, as well as the ability to apply knowledge in real situations, whether at an individual, community or international level.

\section{Assessing the Level of Students' Scientific Literacy}

Science education researchers have been exploring ways to assess the level of students' scientific literacy since the 1960s (Duschl and Grandy, 2013). Cooley and Klopfer (1961) first developed a test on understanding science (TOUS) using scales (categories) of (i) understandings about scientists, (ii) understandings about scientific enterprise, and (iii) understandings about the methods and aims of science. Drawing on this research base, various science education researchers created other tests such as the Nature of Scientific Knowledge survey (Rubba and Anderson, 1978), Conception of Scientific Theory test (Cotham and Smith, 1981), Views of Science and Technology (Aikenhead and Ryan, 1992), and Views of Nature of Science (VNOS) (Lederman et al., 2002). The most recent studies were undertaken by Shahzadi and Nasreen (2020), who drew on Bybee's (1997) idea of scientific literacy levels, and by Ramli et al. (2021), who utilised a scientific literacy test from the PISA instrument. Although scientific literacy tests have been adapted to many contexts and to cater for a range of participants worldwide, in a search of various databases, no studies were found exploring students' scientific literacy in Malaysian and English schools.

Since scientific literacy is part of the school science curriculum in England and Malaysia, an instrument for assessing the level of students' scientific literacy was needed. In the late $20^{\text {th }}$ century, none of the science reform efforts resulted in any significant attempt to assess the degree of scientific literacy of students per se, or to progress toward achieving that goal (Wenning, 2006). Out of the 105 empirical studies that investigated students' VNOS, eleven were based on an unidimensional framework, in which researchers employed closed form instruments and statistical analysis methods in their investigations (Deng et al., 2011). Moreover, as a result of standards-based educational reforms, competency tests in maths and science abound, and are being given on international levels, as represented by such programs as the state-mandated periodic TIMSS (Martin et al., 2012) and PISA (OECD, 2018). These assessments, however, are achievement tests rather than being oriented toward assessing scientific literacy in a comprehensive fashion (Wenning, 2006).

To assess scientific literacy, an accepted baseline with which to gauge students' level of understanding is needed. Consequently, the OECD (2013) definition is used in the study as a baseline and a framework for analysis. This definition was chosen because the organisation is internationally reputable and both countries, England and Malaysia, are members.
OECD (2013) defined scientific literacy as the "ability to engage with science-related issues, and with the ideas of science, as a reflective citizen" (p. 7). This definition includes being able to explain phenomena scientifically, evaluate and design scientific enquiry, and interpret data and evidence scientifically. It acknowledges that a scientifically literate person therefore is willing to engage in reasoned discourse about science and technology and emphasises the importance of being able to apply scientific knowledge in the context of real-life situations. The definition is then expended to include three domain-specific competencies: to i) "explain phenomena scientifically," ii) "evaluate and design scientific enquiry," and ii) "interpret data and evidence scientifically" (OECD, 2013, p. 7).

The first domain-specific competency involves the ability to provide explanatory accounts of natural phenomena, technical artefacts and technologies and their implications for society. Such ability requires knowledge of the major explanatory ideas of science and the questions that frame its practice and goals. The second is the competency to use knowledge and understanding of scientific enquiry to: identify questions that can be answered by scientific enquiry; identify whether appropriate procedures have been used; and propose ways in which such questions might possibly be addressed. The third is the competency to interpret and evaluate data and evidence scientifically and evaluate whether the conclusions are warranted. Therefore, the analysis instrument for this study utilises the scientific processes expanded based on these three domain-specific competencies of scientific literacy. An interpretation of how these three domain-specific competencies are expanded from within the OECD's (2013) definition of scientific literacy is shown in Table 2.

\section{Research Objectives}

Since science education aims to enhance scientific literacy (Holbrook, 2010) and develop competencies needed to be a responsible citizen within society (Roth and Lee, 2004), the two main objectives of this study were to assess the level of secondary students' scientific literacy in suburban schools in Malaysia and England, and to analyse the data using the OECD's three domain-specific competencies of scientific

\begin{tabular}{ll}
\hline $\begin{array}{l}\text { Table 2: The OECD's (2013) } \\
\text { domain-specific competencies of scientific literacy }\end{array}$ \\
\hline $\begin{array}{ll}\text { OECD's (2013) three } \\
\text { domain-specific competencies }\end{array}$ & Definition \\
\hline Explain phenomena scientifically & $\begin{array}{l}\text { Recognise, offer and evaluate } \\
\text { explanations for a range of natural } \\
\text { and technological phenomena. }\end{array}$ \\
$\begin{array}{l}\text { Evaluate and design scientific } \\
\text { enquiry }\end{array}$ & $\begin{array}{l}\text { Describe and appraise scientific } \\
\text { investigations and propose ways of } \\
\text { addressing questions scientifically. }\end{array}$ \\
$\begin{array}{l}\text { Interpret data and evidence } \\
\text { scientifically }\end{array}$ & $\begin{array}{l}\text { Analyze and evaluate data, } \\
\text { claims and arguments in a variety } \\
\text { of representations and draw } \\
\text { appropriate scientific conclusions. }\end{array}$ \\
\hline
\end{tabular}


literacy. These objectives attempted to provide a further understanding of students' scientific literacy in both contexts. Such research has not been previously undertaken, with the exception of the PISA instruments. Thus, the study sought to contribute to the body of knowledge on scientific literacy by filling some of these research gaps. The following research questions were posed: (i) What are the levels of secondary students' scientific literacy in suburban schools in Malaysia and England and (ii) To what extent can students' scientific literacy be explained using the OECD's (2013) definition?

\section{METHODS}

This quantitative study used a purposive sampling technique. Official permission was gained from the two participating suburban secondary schools in Malaysia and England, where the data collection processes were carried out. Both schools were medium sized with a history of their students achieving high pass rates at all levels in the national examinations. A scientific literacy instrument - Wenning's (2006) Nature of Scientific Literacy Test (NOSLiT) - was administered to 30 science students (11 boys and 19 girls) in a suburban secondary school in Malaysia and 30 science students (16 boys and 14 girls) in a suburban school in England $(n=60)$. Both schools' science students were aged between 15 and 16 -years-old. The students came from diverse socioeconomic backgrounds. The majority of their families were middle and lower middle class. All of these students were taking science stream courses, comprised of biology, physics, and chemistry.

The study followed the Malaysian Educational Module on Responsible Conduct of Research published by the Academy of Sciences Malaysia (2018) and the Ethical Guidelines for Educational Research of the British Educational Research Association (2018). Students' participation in this study was completely voluntary, and there were no foreseeable risks associated with participation. Students were free to decline to participate for any reason. They could also stop participating at any time or refuse to answer any individual questions. At the beginning of the study, informed consent between the researcher and students was obtained. Students were informed about the purpose, goals, and aims of the study. They were consulted about their willingness to participate. Nearly, all students required $30 \mathrm{~min}$ to complete the test. The instrument was explained to the students, as well as the fact that the test did not relate to their school examinations, and would have no effect on their studies or results. Students were requested to answer the questions clearly and honestly, according to their understanding. They were also encouraged to complete the answer sheet in their own time. The students' answers have been used for the purposes of this research only and have been kept confidential and anonymous at all times.

The students' answers were analyzed by applying descriptive statistics according to their overall scores and by also separately evaluating their scores in each competency to generate their level of scientific literacy. The results of both the Malaysian and English students were then compared. The scores are presented using means and percentages, and the results are described qualitatively. The analysis indicated that our interpretations of the students' level of scientific literacy, as described in the test, consisted of three domain-specific competencies, as outlined by OECD (2013): to i) explain phenomena scientifically - 12 questions, ii) evaluate and design scientific enquiry - 10 questions, and iii) interpret data and evidence scientifically - 13 questions.

\section{The Instrument to Assess the Level of Students' Scientific Literacy}

The OECD (2013) has developed the basis of an instrument to assess scientific literacy - the major domain for the PISA. The OECD's criteria are valued globally because they provide participating governments with comparable standardised, international indicators of student achievement; however, the current study applied Wenning's (2006) instrument - the NOSLiT - as it would also be able to assess progress toward the more general goal of scientific literacy. NOSLiT was also chosen as an assessment instrument in this study, because it can provide information for the OECD's (2013) three domain-specific competencies. NOSLiT is a 35-item assessment instrument - an untimed test requiring about 30 minutes for nearly all secondary school students to complete, as outlined by Wenning (2006) - with different secondary school students tested. NOSLiT was created as a research instrument for identifying weaknesses in student understanding, improving instructional practice, and determining program effectiveness. An item pool was generated, and each item consisted of a multiple-choice question with four possible answers and true-false questions with only two possible answers.

NOSLiT is a quantitative assessment instrument that was created based on a comprehensive scientific literacy framework. It contrasts with VNOS questionnaires (Lederman et al., 2002), as the latter are designed to induce student perspectives on the nature of science and are not based on a comprehensive nature of science framework. For instance, Wenning (2006) encouraged the widespread use of NOSLiT in a variety of study groups and participant demographics. One of the issues within this study were the method to categorise the level of secondary school students' scientific literacy. Uno and Bybee (1994) have identified four levels of biological literacy - nominal, functional, structural and multi-dimensional - which they refer to as a subset of scientific literacy. They stress that although they have identified four levels, they view scientific literacy development as a continuum, where understanding develops and deepens throughout life. They also believe that a student can display different levels of scientific literacy simultaneously.

Identically, Shamos (1995) suggests that scientific literacy is not something that a person does or does not possess, but rather is something that continues to develop throughout one's life. He introduced three levels of scientific literacy: cultural, functional and true. He describes "cultural" scientific literacy as being found in a person who can recognise science-based terms 
but has no understanding of them. Meanwhile, "functional" literacy requires that the individual not only has a command of a scientific lexicon, but also is able to converse, read and write coherently, using such scientific terms in perhaps a non-technical but nevertheless meaningful context. Finally, "true" scientific literacy occurs when the individual actually knows something about the overall scientific enterprise. Notwithstanding, Ryder (2001) has suggested that rather than being a continuum, there are two dimensions of scientific literacy: functional or non-functional. He used the term functional literacy to describe the scientific knowledge needed by individuals to enable them to function effectively in specific settings.

The OECD (2013) distinguishes six levels of scientific literacy to demonstrate a variety of ways of characterising different levels. They propose more detailed and more specific descriptors of the levels of scientific literacy, and not an entirely different model. The OECD's (2013) level descriptors offer a qualitative description of the differences between the levels of performance that have been incorporated: i) the number and degree of complexity of elements of knowledge demanded by the item, ii) the level of familiarity and prior knowledge that students may have of the content, procedural and epistemic knowledge involved, iii) The cognitive operation required by the item, for example, recall, analysis, evaluation, and iv) the extent to which forming a response is dependent on models or abstract scientific ideas. Henceforth, the OECD (2013), Uno and Bybee (1994), Shamos (1995) and Ryder (2001) all use descriptions to identify levels of scientific literacy, and there is some commonality between their terms, although the meanings they assign to each term differ. Therefore, this study used the levels of scientific literacy provided by the OECD, as an internationally recognized instrument. A summary of the terms used by the OECD (2013) and other researchers is displayed in Table 3.

\section{RESULTS AND DISCUSSION}

In the following, the level of the students' scientific literacy is described with regard to the three domain-specific competencies of the OECD (2013): (i) explaining phenomena scientifically, (ii) evaluating and designing scientific enquiry, and (iii) interpreting data and evidence scientifically. A comparison is made between the Malaysian and English students' level of scientific literacy, and the recommendations of the OECD's definition. Table 4 shows the mean score of NOSLiT for various groups of students. The results indicated that students from Malaysian suburban schools achieved an overall mean score of 17.73 out of 35 , or $51 \%$, while the students from English suburban schools achieved an overall mean of 26.33 , or $75 \%$. The fact that English students have a significantly higher mean score than Malaysian students offers evidence that the overall scientific literacy of suburban schools in England is higher than in Malaysian suburban schools.

The mean scores achieved by the two groups of students in the study are slightly different from those in Wenning's (2006)

\begin{tabular}{|c|c|c|c|}
\hline OECD (2013) & Uno and Bybee (1994) & Shamos (1995) & Ryder (2001) \\
\hline 6 & Multi -dimensional & True & Functional \\
\hline $\begin{array}{l}\text { Develop arguments to critique and evaluate } \\
\text { explanations, models, interpretations of data and } \\
\text { proposed experimental designs } \\
5\end{array}$ & $\begin{array}{l}\text { Ability to interconnect } \\
\text { understandings of } \\
\text { scientific concepts }\end{array}$ & $\begin{array}{l}\text { Having knowledge of the } \\
\text { scientific enterprise and } \\
\text { an awareness of the main } \\
\text { scientific theories }\end{array}$ & $\begin{array}{l}\text { Possession of the scientific } \\
\text { knowledge needed to function } \\
\text { effectively in specific settings }\end{array}$ \\
\hline \multicolumn{4}{|l|}{$\begin{array}{l}\text { Distinguish scientific and non-scientific questions; } \\
\text { explain the purposes of enquiry; and control } \\
\text { relevant variables }\end{array}$} \\
\hline 4 & Structural & & \\
\hline $\begin{array}{l}\text { Draw inferences from different data sources, in a } \\
\text { variety of contexts and explain causal relationships }\end{array}$ & $\begin{array}{l}\text { Ability to understand and } \\
\text { explain scientific concepts }\end{array}$ & & \\
\hline 3 & & Functional & \\
\hline $\begin{array}{l}\text { Show some evidence of linked scientific thinking } \\
\text { and reasoning, usually applied to familiar situations }\end{array}$ & & $\begin{array}{l}\text { Ability to read and write } \\
\text { coherently and use scientific }\end{array}$ & \\
\hline 2 & Functional & terms in meaningful contexts & \\
\hline $\begin{array}{l}\text { Transform and describe simple data, identify } \\
\text { straightforward errors, and make some valid } \\
\text { comments on the trustworthiness of scientific } \\
\text { claims }\end{array}$ & $\begin{array}{l}\text { Ability to define scientific } \\
\text { terms }\end{array}$ & & \\
\hline 1a & & Cultural & \\
\hline $\begin{array}{l}\text { Use a few simple sources of data, in a few contexts } \\
\text { to describe some very simple causal relationships }\end{array}$ & & $\begin{array}{l}\text { Recognition of scientific } \\
\text { terms }\end{array}$ & \\
\hline $1 b$ & Nominal & & \\
\hline $\begin{array}{l}\text { Demonstrate a little evidence to use content and be } \\
\text { able to identify straightforward patterns in simple } \\
\text { sources of data }\end{array}$ & $\begin{array}{l}\text { Scientific term } \\
\text { identification }\end{array}$ & & \\
\hline
\end{tabular}


research. In Wenning's (2006) study, the mean score for the students in six different central Illinois high schools was 20.8 out of $35(59.6 \%)$. The scores, however, are excessive for a test designed to produce the maximum possible spread among scores. Even though the mean scores show the difference between English and Malaysian students as compared to Wenning's (2006) students in the U.S., the current study did not intend to justify the level of students' scientific literacy. Unlike Wenning's (2006) study, which did not categorise students' scientific literacy in terms of specific competencies, Malaysian and English students' scientific literacy in the current study is further analyzed based on the OECD's (2013) definition of three domain-specific competencies, namely: (i) Competency A: explain phenomena scientifically, (ii) Competency B: evaluate and design scientific enquiry, and (iii) Competency $\mathrm{C}$ : interpret data and evidence scientifically. The comparison of the three domain-specific competencies between Malaysian and English students is summarized in Figure 1.

A range of studies in various countries have applied NOSLiT, and it is worth briefly comparing their results. In Murti and Aminah (2018) research, Grade 10 Indonesian students (aged 15-16) scored a mean of 20.8 (59.6\%). The results indicated that $86.2 \%$ of the students already possessed scientific literacy, as measured using Wenning's (2006) framework. Meanwhile, $13.8 \%$ of the students did not possess scientific literacy. In Lebanon, Chatila and Sweid (2020) assessed Grade 10 students' (aged 15-16) scientific literacy using a guided-inquiry teaching approach. The study employed a quasi-experimental design, and the results showed significant changes between the pre- and post-tests. Meanwhile, Garner-O’Neale and Ogunkola (2015) adapted NOSLiT to undergraduate chemistry students in Barbados and reported that the students scored a mean of $24.4(68.6 \%)$. They

\begin{tabular}{lccc}
\hline \multicolumn{4}{l}{ Table 4: Mean scores for two } \\
\hline Groups & N & Mean & Percentage \\
\hline $\begin{array}{l}\text { Malaysian Suburban } \\
\text { School Students }\end{array}$ & 30 & 17.73 & 51 \\
$\begin{array}{l}\text { English Suburban } \\
\text { School Students }\end{array}$ & 30 & 26.33 & 75 \\
\hline
\end{tabular}

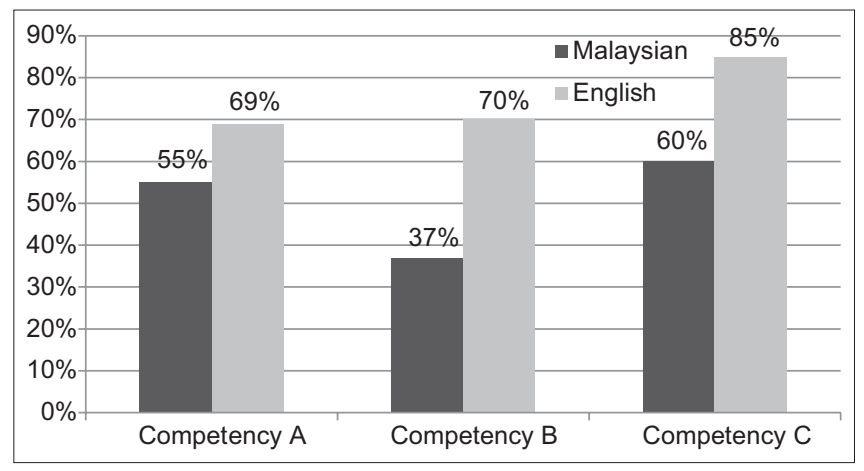

Figure 1: The comparison of Malaysian and English students" scientific literacy across the three domain competencies concluded that the chemistry students were doing reasonably well regarding the nature of scientific literacy compared to physics high school students and teachers in the United States, as described in Wenning's (2006) study.

\section{Competency A: Explain Phenomena Scientifically}

The first scientific literacy competency is to "explain phenomena scientifically," which requires a scientifically literate person to recognise, offer and evaluate explanations for a range of natural and technological phenomena (OECD, 2013). To explain scientific phenomena, one requires the ability to recall and use theories, explanatory ideas, information, and facts, which together are referred to as content knowledge. Offering scientific explanations also require an understanding of how such knowledge has been derived and the level of confidence we might hold about any scientific claims. For this competency, the individual requires knowledge of the standard forms and procedures used in scientific enquiry to obtain such knowledge (procedural knowledge) and an understanding of their role and function in justifying the knowledge produced by science (epistemic knowledge).

The overall score for Competency A - to "explain phenomena scientifically" - showed that the English students achieved higher scores than Malaysian students. The English students' score for this competency was $69 \%$, while the Malaysians only scored $55 \%$. All the questions in this competency were testing students' ability to describe, explain, and predict natural phenomena, which measured their scientific literacy. Twelve questions in the NOSLiT tested the students' scientific literacy with regards to the competency of explaining phenomena scientifically. The example question based on the situation of this competency is "A teacher asks students, "What do you think will happen next?" The teacher is asking for $\mathrm{a}[\mathrm{n}]$ (Question 1). The multiple-choice answers are: (i) hypothesis, (ii) explanation, (iii) principle, and (iv) prediction, and the correct answer is "prediction." The study found that all Malaysian students scored the correct answer on this question (100\%), while the English students did not.

In Ariyanti et al.'s (2016) study, 70\% of Grade 10 students (aged 15-16) answered Question 1 correctly. In their study, this question is scaled as a "scientific nomenclature," which relates to scientific vocabularies. Another question that falls into this category is Question 2, which asks about "theory;" Question 3, which asks about "scientific knowledge;" Question 4, which asks about "models;" Question 5, which asks about "laws;" and Question24, whichasks about"predictions"(Ariyantietal.,2016). Meanwhile, in Henukh et al.'s (2021) study, Competency A was split into two categories: "understand scientific phenomena" and "explain scientific phenomena." The study found that the first category achieved by the students was $66 \%$, and the second category obtained by the students was $62 \%$. Henukh et al. (2021) thus asserted that the students had good scientific literacy in both categories. As a point of comparison, for Competency A, students in Henukh et al.'s (2021) study scored higher than the Malaysian students and lower than the 
English students who participated in the present study.

\section{Competency B: Evaluate and Design Scientific Enquiry}

The aim of the second scientific literacy competency is to "evaluate and design scientific enquiry," which requires a scientifically literate person to describe and appraise scientific investigations and propose ways of addressing questions scientifically (OECD, 2013). Data collected and obtained by means of observation and experiment, either in the laboratory or in the field, leads to the development of models and explanatory hypotheses that enable predictions that can then be tested experimentally. This competency uses content knowledge, knowledge of general procedures used in science (procedural knowledge), and the function of these procedures in justifying the claims put forward by science (epistemic knowledge). Procedural and epistemic knowledge operate for two main purposes. First, such knowledge is required by individuals to evaluate scientific research and decide whether they have followed appropriate procedures and whether the conclusions are justified. Second, individuals with this knowledge should be able to propose, at least broadly, how scientific questions can be accurately investigated.

Ten questions in NOSLiT tested this competency, based on the students' ability to describe and appraise scientific investigations and propose ways of addressing questions scientifically. The results of this study showed that the Malaysian students only scored $37 \%$, which is the lowest percentage of the overall competencies tested in this study. Meanwhile, the English students scored over the mean: 70\%. It is not a surprise that the Malaysian students scored the lowest at $37 \%$ because most of the questions related to this competency could not be answered correctly by Malaysian students. The example question that achieved the lowest result in these tests among both English and Malaysian students was: "A scientific hypothesis is best defined as a: (Question 6)." The multiple-choice answers are: i) well tested explanation supported by lots of evidence from experiments, ii) proposed explanation that incorporates available evidence, iii) statement of the relationship between two variables, and iv) prediction of what will happen. Most of the students, from the test results, could not define a scientific hypothesis correctly; they misunderstood a scientific hypothesis as a prediction of what will happen instead of the correct answer: b) proposed explanation that incorporates available evidence.

As a comparison, in Henukh et al.'s (2021) study, the objective of Competency B was to "identify problems scientifically" based on similar questions from NOSLiT. The study found that the average score obtained by the students was $65 \%$, which is higher than the Malaysian students' scores and lower than the English students' scores in the present study. In relation to Competency B, Question 8 is one of the questions in NOSLiT that falls into this competency. The question asks about the relationship between density, volume, and mass and the correct answer is: c) if more matter is packed more tightly into a fixed volume, the density of that matter will increase.
Findings from the present study revealed that $77 \%$ of English students answered this question correctly, which was more than that calculated for the Malaysian students $(70 \%)$. However, in Murti and Aminah (2018) study, only $41.87 \%$ of students were able to answer Question 8 correctly. They concluded that most of the students who participated in their study were unable to think analytically and understand the questions, so students could not draw a conclusion on their observations and experiments (Murti and Aminah, 2018).

Competency C: Interpret Data and Evidence Scientifically Interpreting data are such a core activity of all scientists that some fundamental understanding of the process is essential for scientific literacy. Initially, data interpretation begins with looking for patterns, constructing simple tables and graphical visualisations such as pie charts, bar graphs, scatterplots, or Venn diagrams (OECD, 2013). At the higher level, it requires the use of more complex datasets, and the use of the analytical tools offered by spreadsheets and statistical packages (OECD, 2013). The scientifically literate person is expected to understand that uncertainty is an inherent feature of all measurements. One criterion for expressing our confidence in a finding is the probability that it may occur by chance. The scientifically literate individual needs to assess whether it is appropriate and subsequent claims are justified. For example, many datasets can be interpreted in a variety of ways. Therefore, argument and critique are very important to determine which conclusion is most accurate.

Thirteen questions tested this competency related to interpreting data and evidence scientifically. From the test results, the study found that most of the students in both Malaysian and English schools answered Question 27, Question 28, and Question 29 correctly. The questions which sought true and false answer were: "After making observations or conducting an experiment, a good scientist will report all evidence, including valid evidence that contradicts the expected outcome (Question 27)," "When scientists judge evidence, they make reference to what they already know about the world (Question 28)," and "A good scientist who is quite certain about conclusions drawn from experimental or observational data should not be afraid of contradicting commonly held beliefs of the scientific community (Question 29)." The overall score of this competency was $85 \%$ for English students and $60 \%$ for Malaysian students. The score of $85 \%$ for the English students is the highest score of all of the three competencies.

In previous work, Henukh et al. (2021) analyzed Grade 8 students' scientific literacy using similar indicators to those used in this study, notably "interpret data and scientific evidence." In this category, they found that the average score obtained by students was $49 \%$ and they interpreted this as a reasonably good category. In comparison, students in Henukh et al.'s (2021) study scored lower than the Malaysian and English students who participated in the present study with regards to Competency C. Question 22 also falls into Competency C. This question asks how scientists make predictions on the basis of 
knowledge put forward by other highly respected scientists who claim to have accurate knowledge of future events. The correct answer for Question 22 is: c) caution the public and wait to see if predictions by the scientist turn out to be true. In the present study, $77 \%$ of students in Malaysia and England suburban schools answered this question correctly. Yet less than $10 \%$ of Grade 10 students (aged 15 to 16) in Ariyanti et al.'s (2016) study answered this question correctly. The students were not able to explain the desirable characteristics of scientists (Ariyanti et al., 2016).

\section{CONCLUSION}

According to Wenning (2006), NOSLiT is best used primarily for the purposes for which it was created: As a research instrument for identifying weaknesses in student understanding, improving instructional practice, and determining program effectiveness. However, the current study was conducted for the purpose of assessing the level of scientific literacy among secondary schools students in Malaysian and English suburban schools. The study also intended to understand students' scientific literacy based on the OECD's (2013) three domain-specific competencies of scientific literacy. The results suggest that future studies should examine the extent to which scientific literacy is independent. As this study has shown, NOSLiT is a system of independent testing that may not develop in a coherent way. Future studies should therefore also focus on studying how to determine the sophistication of scientific literacy through students' arguments surrounding scientific claims, rather than through the three domain-specific competencies of scientific literacy outlined by the OECD (2013). In addition, it is argued that the goal of teaching students scientific literacy is to develop students' abilities to critically evaluate and make decisions regarding scientific claims (see also Smith and Scharmann, 1999; Zeidler et al., 2005). This goal coincides with the suggestion that sophisticated scientific literacy should be interpreted by the degree to which students appropriately argue about scientific claims.

Furthermore, future research should place more emphasis on qualitative methods for both data collection and analysis and should not rely on quantitative methods alone. According to Deng et al., (2011), more than half of their reviewed studies (105 empirical studies) employed open form instruments and content analysis; however, although many studies focused more on explaining scientific literacy qualitatively; they were still quantitative in nature. On the basis of the assumptions of this study, students' responses are categorised according to the OECD's (2013) definition of three domains of competencies, and the frequencies are computed statistically. Hence, the study recommends the availability and analysis of process data (for example, classroom discussions and student-generated artefacts) to allow researchers to investigate how scientific literacy may vary across different learning contexts. Future research should pay more attention to aspects of enquiry in the science classroom when preparing curricular interventions for improving students' scientific literacy. Although this study has not sought to change students' scientific literacy through any particular intervention, it recommends that intervention studies should involve learning activities such as enquiry, discussion, reflection, and/or argumentation.

\section{ACKNOWLEDGMENT}

The completion of this paper was in part supported financially by a research grant from the Council of Trust for Bumiputera, Malaysia (MARA) (Project reference no. 330408220463).

\section{REFERENCES}

Academy of Sciences Malaysia (ASM). (2018). Malaysian Educational Module on Responsible Conduct of Research. Malaysia: Academy of Sciences Malaysia.

Aikenhead, G.S., \& Ryan, A.G. (1992). The development of a new instrument: "Views on science-technology-society" (VOSTS). Science Education, 76(5), 477-491.

American Association for the Advancement of Science (AAAS). (1993). Benchmarks for Science Literacy: Project 2061. Oxford: Oxford University Press.

Ariyanti, A.I.P., Ramli, M., \& Prayitno, B.A. (2016). Preliminary study on developing science literacy test for high school students in Indonesia. Proceeding of International Conference on Teacher Training and Education, 1(1), 284-289.

Banilower, E., Cohen, K., Pasley, J., Weiss, I., \& Horizon Research Inc. (2010). Effective Science Instruction: What Does Research Tell Us? $2^{\text {nd }}$ ed. United States: Horizon Research Inc.

Bloom, B.S. (1956). Taxonomy of Educational Objectives, Cognitive Domain. Vol. 1. United States: McKay.

British Educational Research Association (BERA). (2018). Ethical Guidelines for Educational Research. $4^{\text {th }}$ ed. London, United Kingdom: British Educational Research Association.

Bybee, R.W. (1997). Achieving Scientific Literacy: From Purposes to Practices. New Hampshire, United States: Heinemann.

Chatila, H., \& Sweid, S. (2020). Development of scientific literacy through guided-inquiry learning approach in biology. International Journal of Science and Research, 9(4), 1750-1756.

Cooley, W., \& Klopfer, L. (1961). Test on Understanding Science. New Jersey, United States: Educational Testing Service.

Cotham, J., \& Smith, E. (1981). Development and validation of the conceptions of scientific theories test. Journal of Research in Science Teaching, 18, 387-396.

DeBoer, G.E. (2000). Scientific literacy: Another look at its historical and contemporary meanings and its relationship to science education reform. Journal of Research in Science Teaching, 37(6), 582-601.

Deng, F., Chen, D.T., Tsai, C.C., \& Chai, C.S. (2011). Students' views of the nature of science: A critical review of research. Science Education, 95(6), 961-999.

Department for Education (DfE). (2014). The National Curriculum in England: Framework Document. England, United Kingdom: Department for Education.

Driver, R., Learch, J., Millar, R., \& Scott, P. (1996). Young People's Images of Science. United Kingdom: Open University Press.

Duschl, R.A., and Grandy, R. (2013). Two views about explicitly teaching nature of science. Science and Education, 22(9), 2109-2139.

Fensham, P.J. (2004). Increasing the relevance of science and technology education for all students in the $21^{\text {st }}$ century. Science Education International, 15(1), 7-26.

Garner-O'Neale, L., \& Ogunkola, B. (2015). Effects of interest in science, study habits, sex and level of study on the nature of science literacy level of undergraduate chemistry students of the University of the West Indies, Barbados. Journal of Educational and Social Research, 5(2), 267-267.

Gyllenpalm, J., Wickman, P.O., \& Holmgren, S.O. (2010). Teachers' 
language on scientific inquiry: Methods of teaching or methods of inquiry? International Journal of Science Education, 32(9), 1151-1172.

Henukh, A., Simbolon, M., Astra, I.M., \& Rosdianto, H. (2021). Analysis of students' science literacy ability on heat concept. Journal of Physics Education, 6(2), 178-184.

Hodson, D. (2002). Some thoughts on scientific literacy: Motives, meanings and curriculum implications. Asia-Pacific Forum on Science Learning and Teaching, 3(1), 1-20.

Hodson, D. (2008). Towards Scientific Literacy: A Teachers' Guide to the History, Philosophy and Sociology of Science. Brill Sense.

Holbrook, J. (2010). Education through science as a motivational innovation for science education for all. Science Education International, 21(2), $80-91$.

Hurd, P.D. (1958). Science literacy: Its meaning for American schools. Educational Leadership, 16(1), 13-16.

Kintgen, E.R. (1988). Literacy. Visible Language, 22(2-3), 149-168.

Kolstø, S.D. (2001). Scientific literacy for citizenship: Tools for dealing with the science dimension of controversial socioscientific issues. Science Education, 85(3), 291-310.

Laugksch, R.C. (2000). Scientific literacy: A conceptual overview. Science Education, 84(1), 71-94.

Lederman, N.G., Abd-El-Khalick, F., Bell, R.L., \& Schwartz, R.S. (2002). Views of nature of science questionnaire: Toward valid and meaningful assessment of learners' conceptions of nature of science. Journal of Research in Science Teaching, 39(6), 497-521.

LoPresto, M.C. (2004). Teaching the scientific method in introductory astronomy. Astronomy Education Review, 2(2), 138-145.

Martin, M.O., Mullis, I.V.S., Foy, P., \& Stanco, G. (2012). TIMSS 2011 International Results in Science. In: New Directions for Youth Development. Vol. 2012. TIMSS and PIRLS International Study Center.

McGregor, D., \& Kearton, G. (2010). What do researchers say about scientific literacy in schools? Education in Science, 240, 22-23.

Millar, R. (2006). Twenty first century science: Insights from the design and implementation of a scientific literacy approach in school science. International Journal of Science Education, 28(13), 1499-1521.

Millar, R. (2008). Taking scientific literacy seriously as a curriculum aim. Asia-Pacific Forum on Science Learning and Teaching, 9(2), 1-18.

Millar, R., \& Osborne, J. (1998). Beyond 2000: Science education for the future. In: The Report of a Seminar Series Funded by the Nuffield Foundation.

Ministry of Education Malaysia (MOE). (2003). Integrated Curriculum for Secondary Schools: Science Syllabus. Malaysia: Ministry of Education Malaysia.

Murti, P.R., \& Aminah, N.S. (2018). The analysis of high school students' science literacy based on nature of science literacy test (NOSLiT). Journal of Physics: Conference Series, 1097(1), 1-8.

Norris, S.P., \& Phillips, L.M. (2003). How literacy in its fundamental sense is central to scientific literacy. Science Education, 87(2), 224-240.

Organisation for Economic Co-operation and Development (OECD). (2013). PISA 2015: Draft Science Framework. United Kingdom, France: Organisation for Economic Co-operation and Development.

Organisation for Economic Co-Operation and Development (OECD). (2018). Result from Programme for International Student Assessment (PISA): Malaysia. United Kingdom, France: Organisation for Economic Co-operation and Development.

Osborne, J. (2000). Keynote speech. In: Poisson, M., (Ed.), Science Education for Contemporary Society: Problems, Issues and Dilemmas. Final Report of the International Workshop on the Reform in the Teaching of Science and Technology at Primary and Secondary Level in Asia: Comparative References to Europe. London: International Bureau of Education and Chinese National Commission for UNESCO. pp. 8-14.

Osborne, J. (2007). Science education for the twenty first century. Eurasia Journal of Mathematics, Science and Technology Education, 3(3), 173-184.
Ramli, M., Susanti, B.H., Yohana, M.P., \& Rozak, A. (2021). Assessing Islamic junior high schools students' scientific literacy using PISA released items. Journal of Physics: Conference Series, 1836(1), 1-7.

Ratcliffe, M., \& Millar, R. (2009). Teaching for understanding of science in context: Evidence from the pilot trials of the twenty first century science courses. Journal of Research in Science Teaching, 46(8), 945-959.

Roth, W.M., \& Lee, S. (2004). Science education as/for participation in the community. Science Education, 88(2), 263-291.

Rubba, P., and Anderson, H. (1978). Development of an instrument to assess secondary school students understanding of the nature of scientific knowledge. Science Education, 62(4), 449-458.

Ryder, J. (2001). Identifying science understanding for functional scientific literacy. Studies in Science Education, 36(1), 1-44.

Sadeh, I., \& Zion, M. (2009). The development of dynamic inquiry performances within an open inquiry setting: A comparison to guided inquiry setting. Journal of Research in Science Teaching, 46(10), $1137-1160$.

Shahzadi, I., \& Nasreen, A. (2020). Assessing scientific literacy levels among secondary school science students of district Lahore. Bulletin of Education and Research, 42(3), 1-21.

Shamos, M.H. (1995). The Myth of Scientific Literacy. New Jersey, United States: Rutgers University Press.

Sikas, N. (2017). Enhancing scientific literacy through implementation of inquiry-based science education (IBSE) in Malaysia science curriculum. International Journal of Academic Research in Business and Social Sciences, 7(2), 769-777.

Smith, M.U., \& Scharmann, L.C. (1999). Defining versus describing the nature of science: A pragmatic analysis for classroom teachers and science educators. Science Education, 83(4), 493-509.

Syed Zin, S. M. (2000). Current trends and main concerns as regards science curriculum development and implementation in Asia: Malaysia. In: Poisson, M., (Ed.), Science Education for Contemporary Society: Problems, Issues and Dilemmas. Final Report of the International Workshop on the Reform in the Teaching of Science and Technology at Primary and Secondary Level in Asia: Comparative References to Europe. London: International Bureau of Education and Chinese National Commission for UNESCO. pp. 39-45.

Syed Zin, S.M. (2003). Reforming the science and technology curriculum: The smart school initiative in Malaysia. Prospects, 33(1), 39-50.

Tippins, D.J., Nichols, S.E., Bryan, L.A., Amadou, B., Chun, S., Ikeda, H., McKinley, E., Parker, L., \& Herrera, L.R. (2000). International science educators' perceptions of scientific literacy. In: Abell, S.K., (Ed.), Science Teacher Education. Berlin, Germany: Springer. pp. 193-221.

Toplis, R. (2010). How Science Works: Exploring Effective Pedagogy and Practice. England, UK: Routledge.

Toplis, R., Golabek, C., \& Cleaves, A. (2010). Implementing a new science national curriculum for England: How trainee teachers see the how science works strand in schools. Curriculum Journal, 21(1), 65-76.

Uno, G.E., \& Bybee, R.W. (1994). Understanding the dimensions of biological literacy. Bioscience, 44(8), 553-557.

Wellington, J., and Osborne, J. (2001). Language and Literacy in Science Education. United Kingdom: Open University Press.

Wenning, C.J. (2006). Assessing nature-of-science literacy as one component of scientific literacy. Journal of Physics Teacher Education Online, 3(4), 3-14.

Wheeler, G.F. (2007). Strategies for science education reform. Educational Leadership, 64(4), 30-34.

Zeidler, D.L., Sadler, T.D., Simmons, M.L., \& Howes, E.V. (2005). Beyond STS: A research-based framework for socioscientific issues education. Science Education, 89(3), 357-377.

Zion, M., Shapira, D., Slezak, M., Link, E., Bashan, N., Brumer, M., Orian, T., Nussinovitch, R., Agrest, B., \& Mendelovici, R. (2004). Biomind-a new biology curriculum that enables authentic inquiry learning. Journal of Biological Education, 38(2), 59-67. 